\title{
Effect of Spinecor brace on pulmonary functions
}

\author{
Ö Ersen ${ }^{*}$, N Can, E Oguz, S Bilgic, A Sehirlioglu \\ From 9th International Conference on Conservative Management of Spinal Deformities - SOSORT 2012 \\ Annual Meeting \\ Milan, Italy. 10-12 May 2012
}

\section{Background}

Brace treatment in idiopathic scoliosis is the only efficacious method of non operative treatment. The effect of dynamic SpineCor brace on pulmonary functions is not documented.

\section{Aim}

The aim of this study is to evaluate the immediate effect of SpineCor brace on pulmonary functions.

\section{Methods}

A total of 76 consecutive adolescent idiopathic scoliosis patients who were treated with brace included in this study. 20 of 45 patients who were treated with SpineCor brace, and 13 of 31 patients who were treated with rigid brace, were able to finish pulmonary function test (PFT). PFT is administered to 33 patients before and immediately after wearing the brace. TLC, RV, RV/TLC, FVC, FEV1, FEV1/FVC, FEF25-75 parameters of PFT are compared between SpineCor and rigid brace patients.

\section{Results}

Average age of SpineCor group was 12.6, and average age of rigid brace group was 12.3. Cobb angle was 36.4 \pm $7.3^{\circ}$ in SpineCor group, and $36 \pm 6.9^{\circ}$ in rigid. According to pulmonary function tests, there were no differences between the groups. After wearing the brace, in both groups, restrictive changes were seen, and there were no statistical difference between groups, except FEV 1 parameter $(\mathrm{p}=0,023)$.

\section{Conclusions}

Although SpineCor brace is a non rigid dynamic brace, it has a similar restrictive effect on pulmonary functions

\footnotetext{
Gulhane Military Medical Academy, Ankara, Turkey
}

like rigid braces. Further studies with larger groups are needed.

Published: 3 June 2013

\section{References}

1. Katsaris G, Loukos A, Valavanis J, Vassiliou M, Behrakis PK: The immediate effect of a Boston brace on lung volumes and pulmonary compliance in mild adolescent idiopathic scoliosis. Eur Spine J 1999, 8(1):2-7.

2. Pehrsson $K$, Danielsson $A$, Nachemson A: Pulmonary function in adolescent idiopathic scoliosis: a 25 year follow up after surgery or start of brace treatment. Thorax 2001, 56(5):388-393.

doi:10.1186/1748-7161-8-S1-O46

Cite this article as: Ersen et al:: Effect of Spinecor brace on pulmonary functions. Scoliosis 2013 8(Suppl 1):O46.

\section{Submit your next manuscript to BioMed Central and take full advantage of: \\ - Convenient online submission \\ - Thorough peer review \\ - No space constraints or color figure charges \\ - Immediate publication on acceptance \\ - Inclusion in PubMed, CAS, Scopus and Google Scholar \\ - Research which is freely available for redistribution \\ Submit your manuscript at www.biomedcentral.com/submit}

\section{() Biomed Central}

(c) 2013 Ersen et al; licensee BioMed Central Ltd. This is an Open Access article distributed under the terms of the Creative Commons Attribution License (http://creativecommons.org/licenses/by/2.0), which permits unrestricted use, distribution, and reproduction in any medium, provided the original work is properly cited. 